\title{
Corrigendum: Reductive Power Generated by Mycobacterium leprae Through Cholesterol Oxidation Contributes to Lipid and ATP Synthesis
}

\section{OPEN ACCESS}

Edited and reviewed by: Rey Carabeo,

University of Nebraska Medical Center, United States

${ }^{*}$ Correspondence: Marcia Berrêdo-Pinho mberredo@ioc.fiocruz.br

${ }^{t}$ These authors have contributed equally to this work and share first authorship

Specialty section: This article was submitted to Bacteria and Host,

a section of the journal Frontiers in Cellular and Infection Microbiology

Received: 26 August 2021 Accepted: 10 September 2021 Published: 28 September 2021

Citation:

Rosa TLSA, Marques MAM, DeBoard Z, Hutchins K, Silva CAA, Montague CR, Yuan T, Amaral JJ, Atella GC, Rosa PS, Mattos KA, VanderVen BC, Lahiri R, Sampson NS, Brennan PJ, Belisle JT, Pessolani MCV and Berrêdo-Pinho M (2021) Corrigendum: Reductive Power

Generated by Mycobacterium leprae Through Cholesterol Oxidation Contributes to Lipid and ATP Synthesis. Front. Cell. Infect. Microbiol. 11:765326. doi: 10.3389/fcimb.2021.765326

\begin{abstract}
Thabatta L. S. A. Rosa ${ }^{1 \dagger}$, Maria Angela M. Marques ${ }^{2 \dagger}$, Zachary DeBoard ${ }^{2}$, Kelly Hutchins ${ }^{2}$, Carlos Adriano A. Silva ${ }^{1}$, Christine R. Montague ${ }^{3}$, Tianao Yuan ${ }^{4}$, Julio J. Amaral ${ }^{5}$, Georgia C. Atella ${ }^{6}$, Patrícia S. Rosa ${ }^{7}$, Katherine A. Mattos $^{8}$, Brian C. VanderVen ${ }^{3}$, Ramanuj Lahiri ${ }^{9}$, Nicole S. Sampson ${ }^{4}$, Patrick J. Brennan ${ }^{2}$, John T. Belis/e ${ }^{2}$, Maria Cristina V. Pessolani ${ }^{1}$ and Marcia Berrêdo-Pinho ${ }^{1 *}$

${ }^{1}$ Laboratório de Microbiologia Celular, Instituto Oswaldo Cruz, Fundação Oswaldo Cruz, Rio de Janeiro, Brazil, ${ }^{2}$ Department of Microbiology, Immunology and Pathology, Colorado State University, Fort Collins, CO, United States, ${ }^{3}$ Department of Microbiology and Immunology, Cornell University, Ithaca, NY, United States, ${ }^{4}$ Department of Chemistry, Stony Brook University, Stony Brook, NY, United States, ${ }^{5}$ Laboratório de Química Biológica, Diretoria de Metrologia Aplicada às Ciências da Vida, Instituto Nacional de Metrologia, Qualidade e Tecnologia, Rio de Janeiro, Brazil, ${ }^{6}$ Laboratório de Bioquímica de Lipídeos e Lipoproteínas, Instituto de Bioquímica Médica, Universidade Federal do Rio de Janeiro, Rio de Janeiro, Brazil, ${ }^{7}$ Divisão de Pesquisa e Ensino, Instituto Lauro de Souza Lima, Bauru, Brazil, ${ }^{8}$ Departmento de Controle de Qualidade, Instituto de Tecnologia em Imunobiológicos, Fundação Oswaldo Cruz, Rio de Janeiro, Brazil, ${ }^{9}$ Department of Health and Human Services, Health Resources and Services Administration, Healthcare Systems Bureau, National Hansen's Disease Programs, Baton Rouge, LA, United States
\end{abstract}

Keywords: Mycobacterium leprae, cholesterol, cholestenone, PGL-I, PDIM, 3ß-HSD, reductive power, oxidation

\section{A Corrigendum on}

Reductive Power Generated by Mycobacterium leprae Through Cholesterol Oxidation Contributes to Lipid and ATP Synthesis

by Rosa TLSA, Marques MAM, DeBoard Z, Hutchins K, Silva CAA, Montague CR, Yuan T, Amaral JJ, Atella GC, Rosa PS, Mattos KA, VanderVen BC, Lahiri R, Sampson NS, Brennan PJ, Belisle JT, Pessolani MCV and Berrêdo-Pinho M (2021). Front. Cell. Infect. Microbiol. 11:709972. doi: 10.3389/fcimb.2021.709972

\section{ERROR IN FIGURE/TABLE}

In the original article, there was a mistake in Figure 4: M. leprae 3b-HSD is a source of reductive power as published. Instead of original Figure 4 image, the Supplementary Figure 4 was duplicated and published as Figure 4, and the correct one is not on the published version of the article. The corrected Figure 4: $M$. leprae 3b-HSD is a source of reductive power appears below. The authors apologize for this error and state that this does not change the scientific conclusions of the article in any way. The original article has been updated.

Publisher's Note: All claims expressed in this article are solely those of the authors and do not necessarily represent those of their affiliated organizations, or those of the publisher, the editors and the reviewers. Any product that may be evaluated in this article, or claim that may be made by its manufacturer, is not guaranteed or endorsed by the publisher.

Copyright (c) 2021 Rosa, Marques, DeBoard, Hutchins, Silva, Montague, Yuan, Amaral, Atella, Rosa, Mattos, VanderVen, Lahiri, Sampson, Brennan, Belisle, Pessolani and Berrêdo-Pinho. This is an open-access article distributed under the terms of the Creative Commons Attribution License (CC BY). The use, distribution or reproduction in other forums is permitted, provided the original author(s) and the copyright owner(s) are credited and that the original publication in this journal is cited, in accordance with accepted academic practice. No use, distribution or reproduction is permitted which does not comply with these terms. 
A

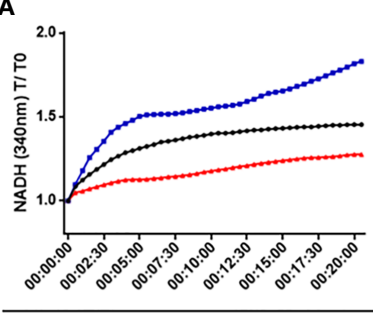

B

(1)
C

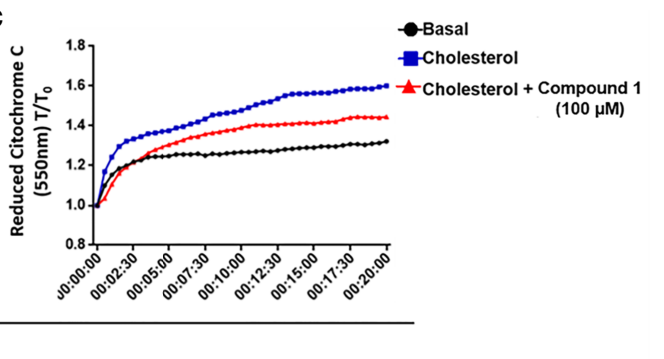

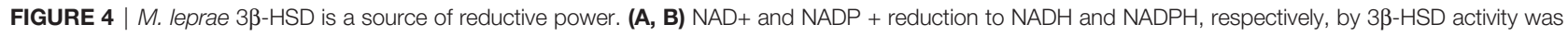
measured in a temporal kinetic curve every $30 \mathrm{~s}$ for $20 \mathrm{~min}$ at $340 \mathrm{~nm}$. (C) Cytochrome $\mathrm{C}$ reduction was determined measuring the reduced form of Cytochrome $\mathrm{C}$ at $550 \mathrm{~nm}$ every $30 \mathrm{~s}$ for $20 \mathrm{~min}$. In all conditions M. leprae WCL was incubated with $200 \mu \mathrm{M}$ cholesterol, alone (blue) or in the presence of $100 \mu \mathrm{M}$ compound 1 (red). A condition without cholesterol addition was also included as a control of basal levels (black). Representative of 3 independent experiments. 